\title{
Penilaian Efisiensi Saham Syariah dengan Pendekatan Sharia Compliant Asset Pricing Model pada Jakarta Islamic Index
}

\author{
Valuation effeciency of sharia stock with sharia compliant asset pricing model in Jakarta \\ Islamic Index
}

\author{
Abdurrohman \\ Program Studi D4 Keuangan Syariah, Politeknik Negeri Bandung \\ E-mail: abdurrohman.ksy16@polban.ac.id
}

\section{Diharpi Herli Setyowati}

Jurusan Akuntansi, Politeknik Negeri Bandung

E-mail: diharpi.herli@polban.ac.id

\section{Tjetjep Djuwarsa}

Jurusan Akuntansi, Politeknik Negeri Bandung

E-mail: tjetjep.djuwarsa@polban.ac.id

\begin{abstract}
The purpose of this study is to analyze the efficiency of Islamic stocks in several companies which are listed on the Jakarta Islamic Index (JII) from January 2014 to November 2018. This study uses the Shari'a Compliant Asset Pricing Model (SCAPM) method modification of the Capital Asset Pricing Model (CAPM) to be appropriate with sharia principles. The variables of this study are Stock Return (Ri), Market Return (Rm), Stock Beta ( $\beta$ ), SBIS Yields, Requred Rate of Return (RRR). The sample in this study is determined by using purposive sampling. This research is a type of descriptive quantitative research and data collection technique is from the documentation of secondary quantitative data, then they are all processed by Microsoft Excel. The results of this study, from 12 samples of sharia stocks shows that there are 7 sharia stocks classified as efficient and 5 sharia stocks classified as inefficient.
\end{abstract}

Keywords: stock, sharia, efficient, SCAPM.

\section{Pendahuluan}

Negara dengan jumlah penduduk Muslim terbesar di dunia adalah Indonesia. Berdasarkan data yang dilansir oleh The Pew Forum on Religion \& Public Life, penganut agama Islam di Indonesia sebesar 209,1 juta jiwa atau 87,2\% dari total semua penduduk. Jumlah ini merupakan 13,1\% dari seluruh umat muslim yang ada di dunia (Kusnandar, 2019). Besarnya jumlah penduduk muslim di Indonesia menjadi potensi besar bagi keuangan syariah untuk dapat tumbuh dan berkembang dengan pesat (Setiawan, Putri Wulansari, 2020). Hal ini menjadikan Indonesia sebagai pasar bagi produk-produk keuangan syariah yang terus berkembang terutama di pasar modal syariah. Kualitas laba yang sangat baik adalah salah satu alasan investor tertarik dengan saham syariah (Zainul, Hasan, 2017) . 


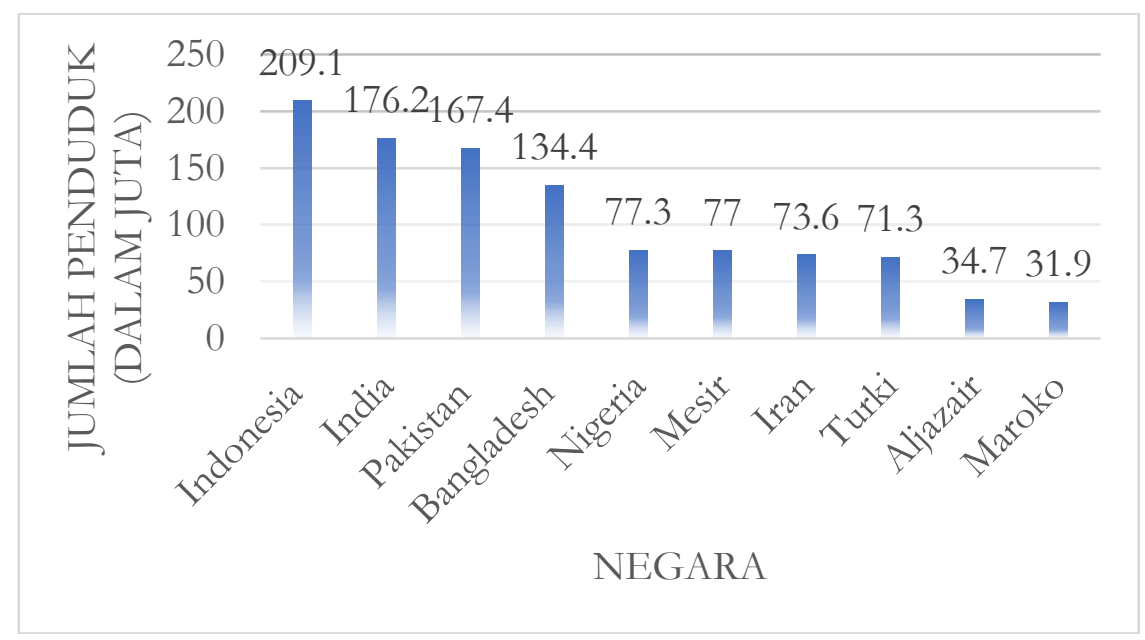

Gambar 1. Negara Dengan Jumlah Penduduk Muslim Terbesar Di Dunia

Investasi pada hakikatnya merupakan penempatan sejumlah dana pada saat ini dengan harapan memperoleh keuntungan di masa mendatang. Tujuan mencari keuntungan meerupakan pembeda antara investasi dan menabung. Dalam melaksanakan kegiatan investasi, investor harus menghadapi dua hal yakni risiko dan return. Dua hal tersebut selalu menjadi alasan investor dalam memilih emiten untuk kualitas laba perusahaan syariah yang lebih tinggi dibanding perusahaan lainnya. Secara teoritis risiko dan return memiliki hubungan yang positif. Seorang investor akan mempertimbangkan risiko and return dalam investasi yang dilakukannya (Fahmi, 2012)

Hal ini membuat investor akan membuat estimasi terhadap saham yang akan dipilih untuk mendapatkan tingkat pengembalian yang efisien. Menurut Jogiyanto (2013) saham efisien merupakan saham-saham dengan tingkat pengembalian individu lebih besar dari pengembalian yang diharapkan. Dalam dunia keuangan konvensional konsep resiko and return pertama kali dipopulerkan oleh Markowizt (1952), dengan memperkenalkan model yang disebut sebagai twoparameter yaitu return yang diharapkan dari suatu asset dan resiko yang dilihat dari standar deviasi return asset tersebut (Muhammad, 2014). Model yang telah dipopulerkan Markowitz tersebut kemudian dikembangkan oleh William Sharpe, Litnet dan Mossin (1960) yang memperkenalkan CAPM (Capital Asset Pricing Model). Dalam hal ini CAPM menjelaskan hubungan antara return dan risiko.

Suatu model atau pendekatan selalu mempunyai kelemahan, tidak dipungkiri model CAPM telah banyak dikritik oleh banyak peneliti mengenai pinjaman bebas risiko. Investor memaksimalkan investasi pada satu periode dan fokus hanya pada risiko dan pengembalian pada satu periode portopolio (Elbannan M. A., 2015). Dalam investasi syariah tidak diperbolehkan return yang bebas risiko. Terlebih lagi $R_{f}$ mempresentasikam nilai waktu uang yang sama dengan riba, sehingga harus dilakukan modifikasi dalam model CAPM. Sudah banyak penulis/pihak yang memodifikasi CAPM, salah satu modifikasi yang bisa dilakukan yakni dengan membentuk model CAPM sesuai prinsip syariah karena investor Muslim harus patuh terhadap prinsip syariah. Hanif (2011) mencoba merumuskan hubungan risiko dan return dalam model syariah. Menurutnya terdapat kebutuhan untuk menganalisis model harga sekuritas yang didasarkan pada nilai-nilai kepatuhan syariah, mencocokkan dengan sistem keuangan syariah dan membetuk alternatif yang diperlukan.

Dari uraian diatas, penulis tertarik untuk menganalisis saham syariah efisien yang terdaftar pada JII secara konsisten menggunakan model SCAPM (Shari'a Compliant Asset Pritig Model) yang merupakan modifikasi dari CAPM dengan judul "Penilaian Efisiensi Saham Syariah Dengan Pendekatan Shari'a Compliant Asset Pricing Model Pada Jakarta Islamic Index". 


\section{Kajian Pustaka}

\subsection{Investasi}

Pada hakekatnya investasi bertujuan untuk menghasilkan uang. Investasi merupakan suatu aktivitas menempatkan dana pada suatu periode tertentu dengan harapan penggunaan dana tersebut bisa menghasilkan keuntungan dan/atau peningkatan nilai investasi. Seseorang yang berinvestasi dikenal sebagai investor, apabila investor menanamkan uangnya maka ia akan mengharapkan, memperoleh uang pengembalian yang lebih banyak di masa mendatang.

\subsection{Pasar Modal Syariah}

Menurut Soemitra (2009) istilah pasar modal biasanya digunakan istilah bursa, eexchange dan market. Sementara untuk istilah modal sering digunakan istilah efek, securities, dan stock. Pasar modal menurut Undang-Undang No. 8 tahun 1995 tentang pasar modal pasal 1 ayatt (12) adalah kegiatan yang bersangkutan dengan Penawaran Umum dan Perdagangan Efek, Perusahaan Publik yang berkaitan dengan efek. Sedangkan yang dimaksukan dengan efek pada pasar 1 ayat (5) adalah surat berharga, yaitu surat pengakuan utang, surat berharga komersial, saham, obligasi, tanda bukti utang, unit penyertaan kontrak investasi kolektif, kontra berjangka atas efek, dan setiap derivatif dari efek.

\subsection{Pengertian Saham}

Salah satu instrumen keuangan yang diperdagangkan di pasar modal Indonesia adalah saham. Saham dapat didefinisikan sebagai tanda penyertaan modal seseorang atau pihak (badan usaha) dalam suatu perusahaan atau perseroan terbatas. Dengan menyertakan modal tersebut, maka pihak tersebut memiliki klaim atas pendapatan perusahaan, klaim atas aset perusahaan, dan berhak hadir dalam Rapat Umum Pemegang Saham (RUPS). Menerbitkan saham merupakan salah satu pilihan perusahan dalam memutuskan pendanaan perusahaannya (Tandelilin, 2010).

Menurut iiiDarmadjiiidan Fakhruddin (2011) saham (shares) didefinisikan sebagai tanda penyertaan atau pemilikan seseorang atau badan dalam suatu perusahaan atau perseroan terbatas. Saham berwujud selembar kertas yang menerangkan bahwa pemilik kertas tersebut adalah pemilik perusahaan yang menerbitkan surat berharga tersebut. Berinvestasi dengan membeli saham pada suatu perusahaan berarti seorang investor telah meinvestasikan dana dengan harapan akan mendapatkan keuntungan dari hasil penjualan kembali saham tersebut. Wujud saham adalah selembar kertas yang menerangkan bahwa pemilik kertas tersebut adalah pemilik perusahaan yang menerbitkan surat berharga tersebut dan porsi kepemilikan ditentukan oleh seberapa besar pernyataan yang ditanamkan dalam perusahaan tersebut.

\subsection{Alat Analisis Identifikasi Portofolio Saham}

Dalam memprediksi return portofolio saham, banyak peneliti-peneliti yang sudah mengalisis menggunakan suatu model atau alat sebagai upaya optimalisasi portofolio saham. Pada tahun 1952, berkembang teori portofolio modern (Modern Portofolio Selection) yang dikenalkan oleh Harry Markowitz yakni Metode Markowitz. Kerangka kerja dari teori portofolio modern yakni pengurangan risiko melalui diversifikasi dapat dicapai. Barulah 12 tahun kemudian muncul Capital Asset Pricing Model (CAPM) yang dikenalkan oleh Sharpe While Linter yang digunakan untuk memprediksi return sehinggga dapat diketahui efek risiko terhadap nilai suatu aset.

\subsection{Shari'a Compliant Asset Pricing Model}

Metode eiiSCAPM $_{\text {iim }}$ erupakan iibetuk $_{\text {iim }}$ odifikasiiidari CAPM yang ditujukan untuk mengukur risiko dan return dalam kerangka syariah. Seperti diketahui CAPM lahir dari lingkungan bunga yang tidak sesuai dengan ajaran syariat Islam. Dalam CAPM terdapat komponen bebas risiko (Rf) yang bertentangan dengan prinsip syariah. Hanif (2011) menjelaskan bahwa komponen Rf terdiri dari dua hal, yaitu (1) riil Rf dan (2) biaya infasi. Riil Rf mewakili nilai waktu uang yang berarti 
menjadikan uang sebagai komoditas sehingga dilarang dalam syariat Islam karena merupakan implikasi dari bunga. Di Indonesia sendiri untuk Rf digunakan SBI (Sertifikat Bank Indonesia). Komponen Rf keduaiiadalahiinflasi, karena inflasi belum ada pelarangannya dalam kerangka syariah maka Hanif (2011) membentuk persamaan:

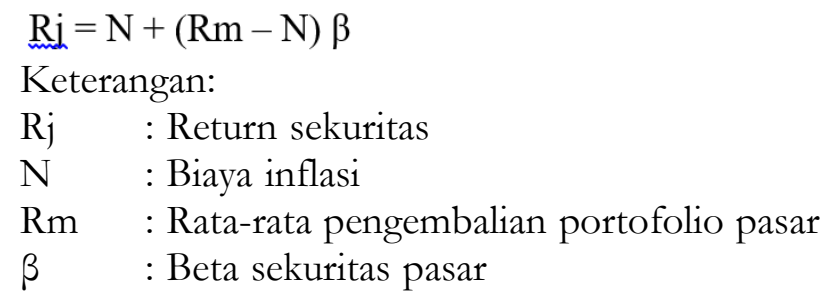

Dimana $\mathrm{Rj}$ merupakan return sekuritas, $\mathrm{N}$ adalah biaya inflasi, $\mathrm{Rm}$ rata-rata pengembalian

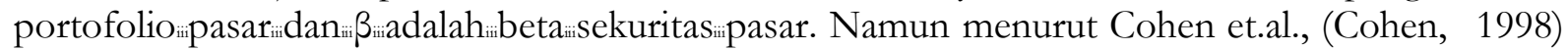
bahwa CAPM diduga gagal ketika menggunakan inflasi. Garis pasar sekuritas CAPM (SML) yang menggambarkan hubungan return rata-rata aset dan beta CAPM lebih curam dari yang diperkirakan ketika inflasi rendah atau negatif. Sebaliknya jika inflasi tinggi, SML akan dangkal dari apa yang diprediksikan oleh Sharpe dan Lintner. Hal ini berarti model dianggap gagal dalam mengontrol kompensasi risiko yang diperlukan investor secara tepat. Dalam asumsi dasar CAPM adalah tidak terjadi inflasi dan ketika inflasi dimasukkan dalam model maka model tersebut diduga gagal. Oleh karena itu dalam penelitian ini komponen yang dimasukkan untuk menggantikan Rf adalah imbalan SBIS (Sertifikat Bank Indonesia Syariah). SBIS sendiri adalah instrumen khusus bank syariah yang menggunakan akad ju'alah sehingga sesuai dengan kerangka syariah. Artinya SBIS bisa dikatakan model syariah dalam menggantikan suku bunga acuan yang dikeluarkan bank Indonesia yang biasanya digunakan sebagai Rf. Adapun kemudian model yang digunakan dalam penelitian ini adalah:

$$
\mathrm{RRR}=\mathrm{SBIS}+(\mathrm{Rm}-\mathrm{SBIS}) \beta \mathrm{i}
$$

Keterangan:

RRR : Tingkat Pengembalian yang Diisyaratkan

SBIS : Sertifikat Bank Indonesia Syariah

Rm : Return Pasar

Bi : Risiko Sistematis

\section{Metode Penelitian}

Jenis penelitian yang digunakan dalam penelitian ini merupakan penelitian deskriptif. Penelitian deskriptif adalah suatu metode penelitian yang menggambarkan semua data atau keadaan subjek/objek penelitan kemudian dianalisis dan dibandingkan berdasarkan kenyataan yang sedang berlangsung saat ini dan selanjutnya mencoba untuk memberikan pemecahan masalahnya (Setiawan, Ratna M. S., 2018). Penelitian ini menggunakan metode Shari'a Compliant Asset Pricing Model (SCAPM) modernisasi dari Capital Asset Pricing Model (CAPM). Penelitian ini memiliki lima variabel. Yaitu return saham (Ri), Return Market (Rm), SBIS, Beta Saham ( $\beta$ ), dan Required Rate of Return (RRR).

Populasi penelitian ini adalah perusahaan yang terdaftar (listing) di indeks saham syariah yakni Jakarta Islamic Index. Teknik sampel yang digunakan dalam penelitian ini adalah purposive sampling, yaitu pengambilan sampel berdasarkan penilaian subyektif peneliti berdasarkan pada karakteristik tertentu yang dianggap mempunyai sangkut paut dengan karakteristik populasi yang sudah diketahui sebelumnya dengan pertimbangan tertentu (Setiawan \& Mauluddi, 2016).

Sampel pada penelitian ini adalah perusahaan yang konsisten terdaftar di Jakarta Islamic Index selama periode 2014-2018 atau selama 5 tahun berturut-turut dan tidak melakukan kebijakan Stock Split. Seleksi sampel penelitian disajikan pada tabel berikut. 
Tabel 1. Daftar Sampel Penelitian

\begin{tabular}{|c|c|c|}
\hline No. & Kode Saham & Nama Emiten \\
\hline 1 & ADRO & PT. Adaro Energy Tbk. \\
\hline 2 & AKRA & PT. AKR Corporindo Tbk. \\
\hline 3 & ASII & PT. Astra International Tbk. \\
\hline 4 & BSDE & PT. Bumi Serpong Damai Tbk. \\
\hline 5 & ICBP & PT. Indofood CBP Sukses Makmur Tbk. \\
\hline 6 & INDF & PT. Indofood Sukses Makmur Tbk. \\
\hline 7 & KLBF & PT. Kalbe Farma Tbk. \\
\hline 8 & SMRA & PT. Summarecon Agung Tbk. \\
\hline 9 & TLKM & PT. Telekomunikasi Indonesia (Persero) Tbk. \\
\hline 10 & UNTR & PT. United Tractors Tbk. \\
\hline 11 & UNVR & PT. Unilever Indonesia Tbk. \\
\hline 12 & SMGR & PT. Semen Indonesia Persero Tbk. \\
\hline
\end{tabular}

Data yang digunakan dalam penelitian ini merupakan data kuantitatif yang menurut sumbernya merupakan data sekunder. Data kuantitatif adalah data yang berbentuk kumpulan angka-angka, sedangkan data sekunder merupakan data yang diperoleh secara tidak langsung. Data sekunder dalam penelitian ini menggunakan data runtut waktu (time series) dan data antar ruang (cross section). Penggabungan kedua data tersebut biasa disebut juga dengan data panel.

\section{Hasil dan Pembahasan}

\subsection{Hasil Analisis Pengembalian Saham Individu}

Tabel2. Pengembalian Saham Individu

\begin{tabular}{|c|l|c|c|}
\hline No & \multicolumn{1}{|c|}{ Nama Perusahaan } & Kode Saham & Ri \\
\hline 1 & PT. Adaro Energy Tbk. & ADRO & 0.007516424 \\
\hline 2 & PT. AKR Corporindo Tbk. & AKRA & 0.002792433 \\
\hline 3 & PT. Astra International Tbk. & ASII & 0.005276687 \\
\hline 4 & PT. Bumi Serpong Damai Tbk. & BSDE & 0.002712919 \\
\hline 5 & PT. Indofod CBP Sukses Makmur Tbk. & ICBP & 0.005288786 \\
\hline 6 & PT. Indofod Sukses Makmur Tbk. & INDF & 0.004195577 \\
\hline 7 & PT. Kalbe Farma Tbk. & KLBF & 0.005027999 \\
\hline 8 & PT. Summarecon Agung Tbk. & SMRA & 0.007632473 \\
\hline 9 & PT. Telekomunikasi Indonesia (Persero) Tbk. & TLKM & 0.010982065 \\
\hline 10 & PT. United Tractors Tbk. & UNTR & 0.008837488 \\
\hline 11 & PT. Unilever Indonesia Tbk. & UNVR & 0.010726235 \\
\hline 12 & PT. Semen Indonesia Persero Tbk & SMGR & 0.000175706 \\
\hline \multicolumn{2}{|c|}{ Rata-rata } & $\mathbf{0 . 0 7 1 1 6 4 7 9 3}$ \\
\hline \multicolumn{2}{|c|}{} & $\mathbf{0 . 0 0 5 9 3 0 3 9 9}$ \\
\hline
\end{tabular}

Hasil dari perhitungan menunjukan bahwa semua sampel saham syariah pada penelitian ini memiliki tingkat pengembalian saham individu yang positif, dengan total semuanya sebesar 0,071164793 dan rata-rata tingkat pengembalian individu dari periode Januari 2014 sampai dengan Desember 2018 sebesar 0,005930399 atau 0,593\%. Saham syariah PT. Telekomunikasi Indonesia (Persero) Tbk. dengan kode saham TLKM memiliki tingkat pengembalian saham individu terbesar yakni 0,010982065 atau 1,09\%. sedangkan PT. Semen Indonesia Persero Tbk. dengan kode saham SMGR memiliki tingkat pengembalian saham individu terkecil sebesar 0,000175706 atau 0,017\%.

\subsection{Hasil Analisis Pengembalian Pasar}

Perhitungan tingkat pegembalian pasar selama periode penelitian Januari 2014 sampai dengan November 2018, menunjukan bahwa tingkat pengembalian pasar tertinggi adalah 0,070109 atau 7,01\% terjadi pada bulan Juni 2016 yang berarti aktivitas perdagangan pada pasar saham cukup aktif. Tingkat pengembalian pasar terendah terjadi pada bulan Maret 2018 sebesar - 
0.08754 atau $-8,75 \%$ yang berarti terjadi kelesuan aktivitas pasar saham pada periode ini. Total pengembalian pasarnya sebesar 0,195263 atau 19,53\% dan rata-rata tingkat pengembalian pasar dari Januari 2014 sampai dengan November 2018 positif sebesar 0,003254 atau 0,33\%. Nilai ratarata yang positif menunjukan sentimen pasar yang positif dan meningkat walaupun pergerakannya sangat kecil. Performance investasi dikatakan baik ketika tingakat pengembalian pasar lebih besar dari tingkat pengembalian bebas resiko. Karena pada peneliatian ini tidak menggunakan unsur bebas resiko dan menggantinya dengan Imbal Hasil SBIS yang menggunakan akad ju'alah sehingga bisa disimpulkan performance investasi saham bisa dikatakan baik (Rm $>$ SBIS).

\subsection{Hasil Analisis Imbal Hasil SBIS}

Perhitungan tingkat imbalan SBIS merujuk pada data yang diterbitkan oleh Bank Indonesia bahwa imbalan SBIS tertinggi pada periode penelitian ini terjadi pada bulan Januari 2014 sebesar 7,23\% atau 0,0723. Sementara imbalan SBIS terendah terjadi pada bulan Februari dan April tahun 2018 sebesar 5,18\% atau 0,0518. Rata-rata tingkat imbalan SBIS dari periode Januari 2014 sampai dengan November 2018 sebesar 0.063695 atau 6,3695\%.

\subsection{Hasil Analisis Risiko Sistematis Beta}

Tabel 3. Risiko Sistematis Beta

\begin{tabular}{|c|l|c|c|c|}
\hline No & \multicolumn{1}{|c|}{ Nama Perusahaan } & Kode Saham & Beta Saham & Keterangan \\
\hline 1 & PT. Adaro Energy Tbk. & ADRO & 1.399605505 & Agresif \\
\hline 2 & PT. AKR Corporindo Tbk. & AKRA & 0.500348099 & Defensif \\
\hline 3 & PT. Astra International Tbk. & ASII & 1.400929611 & Agresif \\
\hline 4 & PT. Bumi Serpong Damai Tbk. & BSDE & 1.391282916 & Agresif \\
\hline 5 & PT. Indofod CBP Sukses Makmur Tbk. & ICBP & 0.575378736 & Defensif \\
\hline 6 & PT. Indofod Sukses Makmur Tbk. & INDF & 1.129769912 & Agresif \\
\hline 7 & PT. Kalbe Farma Tbk. & KLBF & 1.040097275 & Agresif \\
\hline 8 & PT. Summarecon Agung Tbk. & SMRA & 1.839360663 & Agresif \\
\hline 9 & PT. Telekomunikasi Indonesia (Persero) Tbk. & TLKM & 0.778514974 & Defensif \\
\hline 10 & PT. United Tractors Tbk. & UNTR & 0.64654099 & Defensif \\
\hline 11 & PT. Unilever Indonesia Tbk. & UNVR & 0.68746848 & Defensif \\
\hline 12 & PT. Semen Indonesia Persero Tbk & SMGR & 1.115046852 & Agresif \\
\hline \multicolumn{2}{|c|}{ Rata-rata Beta Saham } & $\mathbf{1 . 0 4 2 0 2 8 6 6 8}$ & Agresif \\
\hline
\end{tabular}

Perhitungan risiko sistematis Beta $(\beta)$ dari 12 saham syariah perusahaan yang digunakan sebagai sampel penelitian pada periode Januari 2014 sampai dengan November 2018 menunjukan bahwa beta tertinggi dimiliki oleh PT. Summarecon Agung Tbk. dengan kode saham SMRA sebesar 1,839360663 artinya saham yang memiliki risiko yang tinggi dan tergolong saham agresif karena memiliki nilai beta $(\beta>1)$. Saham yang memiliki beta $(\beta)$ terkecil adalah saham dari PT. AKR Corporindo Tbk. dengan kode saham AKRA yaitu sebesar 0,500348099 artinya saham tersebut memiiki risiko yang rendah dan tergolong defensif karena memiliki nilai beta $(\beta<1)$. Rata-rata beta saham pada penelitian ini periode Januari 2014 sampai dengan November 2018 sebesar 1,042028668 artinya rata-rata saham syariah yang digunakan pada penelitian ini tergolong agresif $(\beta>1)$ karena saham cenderung naik dan turun lebih tinggi dari pada pasar. 


\subsection{Hasil Analisis Required Rate of Return}

Tabel 4. Hasil Analisis Required Rate of Return

\begin{tabular}{|l|c|c|c|c|c|}
\hline \multicolumn{1}{|c|}{ Nama Perusahaan } & $\begin{array}{c}\text { Kode } \\
\text { Saham }\end{array}$ & $\begin{array}{c}\text { Return } \\
\text { Market (Rm) }\end{array}$ & SBIS & $\begin{array}{c}\text { Beta Saham } \\
(\boldsymbol{\beta})\end{array}$ & RRR = SBIS+(Rm-SBIS) $\boldsymbol{\beta}$ \\
\hline PT. Adaro Energy Tbk. & ADRO & 0.003254382 & 0.063695 & 1.399605505 & -0.020897917 \\
\hline PT. AKR Corporindo Tbk. & AKRA & 0.003254382 & 0.063695 & 0.500348099 & 0.03345352 \\
\hline PT. Astra International Tbk. & ASII & 0.003254382 & 0.063695 & 1.400929611 & -0.020977946 \\
\hline PT. Bumi Serpong Damai Tbk. & BSDE & 0.003254382 & 0.063695 & 1.391282916 & -0.020394896 \\
\hline PT. Indofod CBP Sukses Makmur Tbk. & ICBP & 0.003254382 & 0.063695 & 0.575378736 & 0.028918642 \\
\hline PT. Indofod Sukses Makmur Tbk. & INDF & 0.003254382 & 0.063695 & 1.129769912 & -0.004588958 \\
\hline PT. Kalbe Farma Tbk. & KLBF & 0.003254382 & 0.063695 & 1.040097275 & 0.000830888 \\
\hline PT. Summarecon Agung Tbk. & SMRA & 0.003254382 & 0.063695 & 1.839360663 & -0.047476874 \\
\hline PT. Telekomunikasi Indonesia (Persero) Tbk. & TLKM & 0.003254382 & 0.063695 & 0.778514974 & 0.016641015 \\
\hline PT. United Tractors Tbk. & UNTR & 0.003254382 & 0.063695 & 0.64654099 & 0.02461757 \\
\hline PT. Unilever Indonesia Tbk. & UNVR & 0.003254382 & 0.063695 & 0.68746848 & 0.022143898 \\
\hline PT. Semen Indonesia Persero Tbk & SMGR & 0.003254382 & 0.063695 & 1.115046852 & -0.003699091 \\
\hline \multicolumn{4}{|l|}{ Rata-Rata Required Rate Of Return } & 0.000714154 \\
\hline
\end{tabular}

Berdasarkan tabel perhitungan tingkat pengembalian yang diharapkan dari 12 saham syariah perusahaan yang digunakan sebagai sampel penelitian pada periode Januari 2014 sampai dengan November 2018 menunjukan bahwa saham dari PT. AKR Corporindo Tbk. dengan kode saham AKRA merupakan saham dengan tingkat pengembalian yang diharapkan terbesar yaitu 0,03345352 atau 3,35\% \% . Sementara saham dengan tingkat pengembalian yang diharapkan terendah adalah PT. Summarecon Agung Tbk. dengan kode daham SMRA yakni sebesar 0,047476874 atau $-0,47 \%$. Rata-rata tingkat pengembalian saham yang diharapkan selama periode Januari 2014 sampai dengan Desember 2018 sebesar 0,000714154 atau 0,071\%

\subsection{Pengelompokan Saham Efisien}

Tabel 5. Pengelompokan Saham Efisien

\begin{tabular}{|l|c|c|c|c|}
\hline \multicolumn{1}{|c|}{ Nama Perusahaan } & Kode Saham & (Ri) & RRR & Evaluasi Saham \\
\hline PT. Adaro Energy Tbk. & ADRO & 0.007516424 & -0.020897917 & Efisien \\
\hline PT. AKR Corporindo Tbk. & AKRA & 0.002792433 & 0.03345352 & Tidak Efisien \\
\hline PT. Astra International Tbk. & ASII & 0.005276687 & -0.020977946 & Efisien \\
\hline PT. Bumi Serpong Damai Tbk. & BSDE & 0.002712919 & -0.020394896 & Efisien \\
\hline PT. Indofod CBP Sukses Makmur Tbk. & ICBP & 0.005288786 & 0.028918642 & Tidak Efisien \\
\hline PT. Indofod Sukses Makmur Tbk. & INDF & 0.004195577 & -0.004588958 & Efisien \\
\hline PT. Kalbe Farma Tbk. & KLBF & 0.005027999 & 0.000830888 & Efisien \\
\hline PT. Summarecon Agung Tbk. & SMRA & 0.007632473 & -0.047476874 & Efisien \\
\hline PT. Telekomunikasi Indonesia (Persero) Tbk. & TLKM & 0.010982065 & 0.016641015 & Tidak Efisien \\
\hline PT. United Tractors Tbk. & UNTR & 0.008837488 & 0.02461757 & Tidak Efisien \\
\hline PT. Unilever Indonesia Tbk. & UNVR & 0.010726235 & 0.022143898 & Tidak Efisien \\
\hline PT. Semen Indonesia Persero Tbk & SMGR & 0.000175706 & -0.003699091 & Efisien \\
\hline
\end{tabular}

Pengelompokan saham syariah efisien diatas menunjukan bahwa perusahaan dengan kode saham AKRA, ICBP, TLKM, UNTR dan UNVR tergolong saham yang tidak efisien. Keputusan yang diambil investor pada saham yang tidak efisien seharusnya overpriced (menjual saham). Sementara untuk 7 saham syariah lainnya tergolong efisien, sehingga investor bisa mengambil keputusan underprice (membeli saham) atau mempertahankan saham tersebut jika sudah dimiliki. Sesuai dengan kategori investor rasional yang akan memilih saham-saham efisien dan tidak akan memilih saham-saham yang tidak efisien. 


\subsection{Pembahasan}

Tabel 6. Hasil Analisis Semua Variabel

\begin{tabular}{|l|c|c|c|c|c|c|c|}
\hline Kode Saham & $\mathrm{Ri}$ & $\mathrm{Rm}$ & SBIS & Beta $(\beta)$ & RRR & Excess Return & Evaluasi Saham \\
\hline ADRO & 0.00752 & 0.00325 & 0.06369 & 1.39961 & -0.0208979 & 0.02841434 & Efisien \\
\hline AKRA & 0.00279 & 0.00325 & 0.06369 & 0.50035 & 0.03345352 & -0.030661087 & Tidak Efisien \\
\hline ASII & 0.00528 & 0.00325 & 0.06369 & 1.40093 & -0.0209779 & 0.026254633 & Efisien \\
\hline BSDE & 0.00271 & 0.00325 & 0.06369 & 1.39128 & -0.0203949 & 0.023107816 & Efisien \\
\hline ICBP & 0.00529 & 0.00325 & 0.06369 & 0.57538 & 0.02891864 & -0.023629856 & Tidak Efisien \\
\hline INDF & 0.0042 & 0.00325 & 0.06369 & 1.12977 & -0.004589 & 0.008784534 & Efisien \\
\hline KLBF & 0.00503 & 0.00325 & 0.06369 & 1.0401 & 0.00083089 & 0.004197111 & Efisien \\
\hline SMRA & 0.00763 & 0.00325 & 0.06369 & 1.83936 & -0.0474769 & 0.055109348 & Efisien \\
\hline TLKM & 0.01098 & 0.00325 & 0.06369 & 0.77851 & 0.01664102 & -0.00565895 & Tidak Efisien \\
\hline UNTR & 0.00884 & 0.00325 & 0.06369 & 0.64654 & 0.02461757 & -0.015780082 & Tidak Efisien \\
\hline UNVR & 0.01073 & 0.00325 & 0.06369 & 0.68747 & 0.0221439 & -0.011417663 & Tidak Efisien \\
\hline SMGR & 0.00018 & 0.00325 & 0.06369 & 1.11505 & -0.0036991 & 0.003874797 & Efisien \\
\hline
\end{tabular}

Pada penelitian ini, hasil analisis tingkat pengembalian pasar atau return market $(\mathrm{Rm})$ positif sebesar $0,00325(0,32 \%)$ yang menunjukan bahwa selama periode Januari 2014 sampai dengan periode Desember 2018 berinvesatasi pada saham syariah khususnya pada index pasar Jakarta Islamic index masih dapat memberikan keuntungan bagi investor dan perusahaan. Performace investasi dikatalam baik ketika tingkat pengembalian pasar lebih besar dari tingkat pengembalian bebas resiko (Rf). Karena pada penelitian menggunakan pendekatan Shari'a Compliant Asset Pricing Model (SCAPM), modernisasi dari Capital Asset Pricing Model (CAPM) dimana tidak memasukkan unsur bebas resiko dan menggantinya dengan SBIS yang menggunakan akad ju'alah, sehingga bisa disimpulkan performance investasi saham bisa dikatakan baik apabila ( $\mathrm{Rm}>\mathrm{SBIS}$ ). Pada penelitian ini, nilai imbal hasil SBIS sebesar 0,06369 (6,36\%) dimana performance investasinya tidak baik karena nilai pengembalian pasarnya lebih kecil dari SBIS (Rm $<$ SBIS).

Hasil analisis tingkat pengembalian return individu pada penelitian ini, dari periode Januari 2014 sampai dengan Desember 2018 setiap perusahaan hasilya positif, tetapi tidak semua perusahaan dikatakan efisien. Dari 12 sampel saham syariah yang diteliti, terdapat 7 saham syariah yang efisien yaitu perusahaan dengan kode saham ADRO, ASII, BSDE, INDF, KLBF,SMRA, dan SMGR. Saham syariah tidak efisien yaitu perusahaan dengan kode saham AKRA, ICBP, TLKM, UNTR, UNVR. Saham syariah dikatakan efisien apabila return individunya lebih besar dari tingkat pengembalian yang diharapkan atau required rate of return ( $\mathrm{Ri}>\mathrm{RRR})$. sedangkan saham syariah yang tidak efisien, nilai return individunya lebih kecil dari tingkat pengembalian yang diharapkan $(\mathrm{Ri}<\mathrm{RRR})$.

Terdapat beberapa faktor yang membuat saham tidak efisien atau nilai return yang didapatkan oleh perusahaan kecil bahkan negatif, faktor tersebut yaitu makro ekonomi dan internal perusahaan. Faktor makro ekonomi seperti nilai kurs, kebijakan pemerintah, inflasi, suku bunga, peristiwa politik, peristiwa sosial. sedangkan faktor internal perusahaan yaitu profitabilitas, struktur modal, ukuran perusahaan. Pada faktor makro ekonomi, perusahaan harus bisa menerima atau mengantisipasi keadaan tersebut, perusahaan harus bisa menyediakan payung sebelum terjadinya hujan. Salah satu cara agar perusahaan dapat meningkatkan return individunya adalah dengan cara perusahaan meminjam dana atau hutang, kemudian memanfaatkan dana tersebut untuk memperoleh laba operasi yang lebih besar dari beban bunga, maka penggunaan hutang tersebut dapat memberikan keuntungan bagi perusahaan dan akan meningkatkan return bagi pemegang saham. Sebaliknya, jika perusahaan tidak dapat memanfaatkan dana secara baik, perusahaan mengalami kerugian.

Risiko sistematis beta dari 12 saham syariah yang diteliti dalam penelitian ini terdapat 7 saham syariah yang tergolong agresif karena $(\beta>1)$ memiliki risiko yang cukup tinggi, 5 saham syariah 
lainnya tergolong defensif karena $(\beta<1)$ memiliki risiko yang rendah. Perusahaan yang tergolong defensif yaitu perusahaan dengan kode saham AKRA, ICBP, TLKM, UNTR, dan UNVR. Beta saham PT. Summarecon Agung Tbk. atau perusahaan dengan kode saham SMRA memiliki nilai beta yang paling tinggi sebesar 1,83936 dan mendapatkan tingkat pengembalian return invidu yang paling tinggi pula sebesar 0,00763 dari saham syariah yang tergolong efisien. Seperti yang dijelaskan dalam latar belakang penelitian ini, secara teoritis risiko dan return memiliki hubungan yang positif, seorang investor akan mempertimbangkan risiko dan return dalam invetasi yang dilakukannya.

Pada penelitian ini, perusahan yang saham syariahnya tidak efisien memiliki nilai excess return yang negatif, yaitu perusahaan dengan kode saham AKRA sebesar -0,030661087, ICBP sebesar 0,023629856, TLKM sebesar -0,00565895, UNTR sebesar (-0,015780082), dan UNVR sebesar (0,011417663). Saham syariah lainnnya memiliki nilai excess return yang positif, dan yang paling terbesar adalah PT. Summarecon Agung Tbk. perusahaan dengan kode saham SMRA sebesar 0,055109348 .

Pada dasarnya terdapat 3 cara untuk mendapatkan saham, yang pertama yaitu membeli saham di pasar perdana atau ketika sebuah perusahaan melalukan penawaran umum (go public). Kedua membeli saham di pasar sekunder atau membeli saham yang telah tercatat dan diperdagangkan d Bursa Efek, khusus untuk di pasar sekunder terlebih dahulu kita harus menjadi nasabah di salah satu broker saham atau perusahaan sekuritas yang menjadi anggota di Bursa Efek. Yang ketiga membeli saham saham melalui pembelian unit penyertaan reksa dana (melalui reksa dana). Bagi investor, khususnya investor yang memilih jalan kedua yaitu membeli saham di pasar sekunder melalui seorang broker, 7 saham syariah efisien diatas dapat dijadikan suatu pilihan alternatif untuk berinvestasi saham, karena saham-saham syariah tersebut merupakan hasil penyeleksian terbaik, seperti yang dijelaskan diatas. sedangkan untuk perusahaan yang mengeluarkan saham dan menginginkan sahamnya diminati oleh investor terdapat beberapa cara, salah satunya dengan melakukan banyak interaksi dengan masyarakat dan pasar modal. dengan kata lain, perusahaan harus lebih terbuka, hal ini dapat menumbuhkan rasa kepercayaan investor terhadap perusahaan tersebut. Salah satu cara perusahaan berinteraksi yaitu dengan mengadakan public expose.

\section{Penutup}

Berdasarkan perhitungan hasil penelitian dan analisis dari 12 sampel saham syariah perusahaan yang konsisten terdaftar dalam indeks JII, selama periode Januari 2014 sampai dengan November 2018 menggunakan pendekatan Shari'a Compliant Asset Pricing Model (SCAPM), terdapat 7 saham syariah yang masuk dalam kategori saham efisien dengan kode saham ADRO, ASII, BSDE, INDF, KLBF,SMRA, dan SMGR, dimana hasil tersebut didapat berdasarkan nilai return individu saham-sahamnya lebih besar dari nilai return yang diharapkan (Ri>RRR). 5 saham syariah lainnya masuk dalam kategori tidak efisien dengan kode saham AKRA, ICBP, TLKM, UNTR, dan UNVR, karena nilai return individu sahamnya lebih kecil dari nilai return yang diharapkan $(\mathrm{Ri}<\mathrm{RRR})$.

Penelitian ini diharapkan dapat menjadi referensi dan tambahan informasi bagi para investor maupun calon investor yang akan melakukan investasi pada saham di pasar modal khususnya pada Jakarta Islamic index (JII). Sangat penting sekali bagi investor untuk mengetahui saham yang efisien agar return yang diharapkan dapat terwujud. Peneliti dengan pendekatan Sharia Compliant Asset Pricing Model (SCAPM) ini diharapkan dapat dijadikan referensi untuk penelitian selanjutnya dengan sampel dan periode yang berbeda, sehingga perkembangan mengenai pasar modal khususnya investasi saham syariah dapat selalu diketahui dan mendapatkan pemahaman ilmu tentang pendekatan SCAPM. Penelitian ini diharapkan dapat menjadi tambahan referensi dan informasi mengenai ketepatan kinerja maupun perbaikan kinerja perusahaan terutama dalam tingkat pendapatan return individu perusahaannya. 


\section{Daftar Pustaka}

Darmadji, \& F. (2011). Pasar Modal di Indonesia. Salemba Empat.

Elbannan M. A. (2015). The Capital Asset Pricing Model. International Journal of Economic and Finance, 7(1), 222.

Fahmi. (2012). Pengantar Pasar Modal. Alfabeta.

Hanif. (2011). Risk and Return Under Shari'a Framework: An Attempt to Develop Shari'a Compliant Asset Pricing Model (SCAPM). Pakistan Journal Commer Social Science, 5(2), 1.

Jogiyanto, H. (2013). Teori Portofolio dan Analisis Investasi. BPFE.

Kusnandar, V. B. (2019). indonesia-negara-dengan-penduduk-muslim-terbesar-dunia @ databoks.katadata.co.id.

Globalreligiousfutures. https://databoks.katadata.co.id/datapublish/2019/09/25/indonesia-negara-denganpenduduk-muslim-terbesar-dunia

Markowizt, H. (1952). Portofolio Selection. The Journal of Finance, 7(1), 77-91.

Muhammad. (2014). Manajemen Kenangan Syari'ah. LPP STIM YKPN.

Setiawan, Putri Wulansari, R. P. K. D. (2020). Pengukuran Tingkat Kinerja Keuangan Dan Kinerja Non Keuangan Pada Bank Syariah Di Lima Negara Asia. Dinamika Akuntansi Kenangan Dan Perbankan, 9(1), 69-78. https://doi.org/10.1017/CBO9781107415324.004

Setiawan, \& Mauluddi, H. A. (2016). Kinerja Perusahaan: Studi Pengaruh Corporate Governance Melalu Konservatisme Akuntans pada Perusahaan yang Terdaftar di Jakarta Islamic Index. Account: Jurnal Akuntansi, Keuangan Dan Perbankan, 1(5), 368-374.

Setiawan, S. Ratna Mayasari. (2018). Rentabilitas Bank Umum Syariah Sesudah Spin-Off Berdasarkan Tipe Pemisahannya Di Indonesia. Amwaluna: Jurnal Ekonomi Dan Kenangan Syariah, 2(1), 69-87. https://doi.org/10.29313/amwaluna.v2i1.3291

Soemitra, A. (2009). Bank dan Lembaga Keuangan Syariah. Kencana.

Tandelilin, E. (2010). Analisis Investasi dan Manajemen Portofolio. BPFE.

Zainul, Hasan, Q. (2017). Analisis Saham Syariah Efisien dengan Pendekatan Shar 'a Compliant Asset Pricing Model ( SCAPM ) pada Jakarta Islamic Index (JII). 8, 131-147. 